\title{
Scanning and Transmission Electron Microscopy of the Ependymal Lining of the Third Ventricle
}

\author{
J. E. BRUNI
}

SUMMARY: In its simplest form, the ependyma of the third ventricle consists of a single layer of cuboidal cells. Although these typical mural cells constitute the greater part of the lining of the ventricle, a specialized variety of ependymal cell (the tanycyte) can also be distinguished within circumscribed areas of the ventricular wall. Although such cells are found scattered throughout the dorsoventral extent of the third ventricle, they are particularly numerous along the ventrolateral walls and floor. The regional variation in the surface morphology of the ventricle walls as evident with the scanning electron microscope is consistent with this pattern of tanycyte distribution. Ultrastructural studies have established that the tanycyte is a fundamentally distinct cell with a long basal process extending into the

RESUME: L'épendyme du troisième ventricule est constitué essentiellement d'une seule couche de cellules cuboides. Bien que ces cellules murales typiques forment la plupart de l'enveloppe ventriculaire, on peut reconnaitre cependant une variété spéciale de cellules épendymaires (la tancyte) à de régions circonscrites de la paroi ventriculaire. De plus celles-ci, quoiqu'elles soient distribuées de part et d'autre à travers l'étente entière dorso-ventrale du troisième ventricule, sont surtout nombreuses à ses régions ventro-latérales ainsi que son plancher. La variation morphologique régionale des parois ventriculaires observée avec le microscope électronique de balayage est d'accord avec une telle distribution de tancytes. D'études ultrastructurelles ont établique la tancyte soit bien une cellule essen- subjacent neuropil and frequently directed toward a capillary wall. This unique morphology conforms closely to its three-dimensional appearance as demonstrated with the scanning electron microscope. The significance of ependymal tanycytes particularly of the third ventricle derives largely from the connections they establish between the ventricular lumen and vasculature of the median eminence. This intriguing structural relationship has led to the suggestion that ependymal cells and cerebrospinal fluid of the third ventricle may be involved in the regulation of adenohypophysial activity. Evidence indicating the functional involvement of specialized ependymal cells in the neuroendocrine control of pituitary activity is reviewed.

tiellement distincte avec une élongation basale rejoignant le neuropil sous-jacent et fréquemment dirigé vers une paroi capillaire. Cette morphologie unique conforme bien à son apparence en trois dimensions au microscope électronique de balayage. L'importance de tancytes épendymaires du troisième ventricule survient surtout des interconnections qu'elles établissent entre le troisième ventricule même et la vasculature de l'éminence médiane. Cette dernière relation structurelle a donné origine à la suggestion que les cellules épendymaires ainsi que le liquide céphalorachidien du troisième ventricule puissent participer au contrôle d'activité adénohypophysaire. Evidence de participation fonctionnelle de cellules épendymaires spécialisées au contrôle neuroendocrinien d'activité pituitsire est ici discuté.

From the Department of Anatomy. Health Sciences Centre, University of Western Ontario. London. Ontario. Canada.

Reprint Address - J. E. BRUNI, Dept. of Anatomy, University of Western Ontario, London 72 , Ontario.

\section{Introduction:}

Purkinje (1836) is credited with being the first to document the character of the epithelial lining of the cerebral ventricles. The introduction of metal impregnation techniques some years later awakened renewed interest in the subject and much new information concerning the morphology of the ependymal cell was soon obtained. Reviews of the earliest literature on this subject Studnicka (1900), Agduhr (1932), Wislocki (1932), indicate that the early investigators recognized the wide variation in ependymal cell morphology, and in particular, that some cells have long basal extensions incorporated into the brain parenchyma. There was little consensus in the terminology applied to these extensions until Horstmann (1954) introduced the descriptive term - tanycyte - for the elongated ependymal cells of Selachians that stained with the Cajal gold sublimate method. They were distinguishable from common mural ependyma by virtue of their long basal processes which extend into the subjacent neuropil. In recent years, the specialized ependymal cells situated along the floor and lateral walls of the infundibular recess (IR) have received particular attention because of the morphological link they establish between the cerebrospinal fluid (CSF) on the one hand, and the pars tuberalis and the vasculature of the median eminence (ME) on the other. This intriguing structural relationship led Lofgren (1959) (1960), to initially suggest a possible involvement in the neuroendocrine control of pituitary function. Although much inferential and speculative evidence of such an involvement has been subsequently 
adduced, their precise nature and function is far from clear and merits further investigation.

\section{Principal Cell Types in} the Ventricular Wall:

\section{Distribution and Ultrastructure}

Light and electron microscopy have been used to elucidate the fine structural details of the cerebral ventricular system in a number of species. Regional differences in the structure of both the ependyma and subependymal layers of the ventricles have been observed Fleischhauer (1961), Klinkerfuss (1964), Schimrigk (1966), Tennyson and Pappas (1968). The walls of the ventricles are generally lined with a continuous epithelium that varies from flattened squamous-like to cuboidal-columnar, with and without cilia and cell processes. Variations, however, in stratification and morphology occur with age, species, sex and location within the ventricular walls.

Several ependymal cell variants classified according to their morphology have been described Tennyson and Pappas (1962) Knowles and Anand Kumar (1969), Anand Kumar (1972), Knowles (1972), Millhouse (1972), Sharp (1972). In its simplest form, the ependyma of the rabbit third ventricle consists of a single layer of cuboidal cells (Fig. 1). The typical mural ependymal cell comprises the greater part of the lining of the third ventricle (re: section 4), and is, with minor exceptions, fundamentally similar to the characteristic ependyma described in other mammalian species Brightman and Palay (1963), Klinkerfuss (1964), Malinsky (1968), Knowles and Anand Kumar (1969), Westergaard (1970), Millhouse (1972). The luminal plasma membrane is complexly organized into numerous microvillilike projections approximately 0.04-0.07 $\mathrm{umin}$ diameter and tufts of cilia (Fig. 2). Projections of the juxtaventricular surface may contain small pits and vesicles, however cytoplasmic organelles are rarely included. Cilia are of indeterminate length, approximately $0.22 \mu \mathrm{m}$ in diameter, and have the usual inner arrangememnt of 9 peripheral doub-

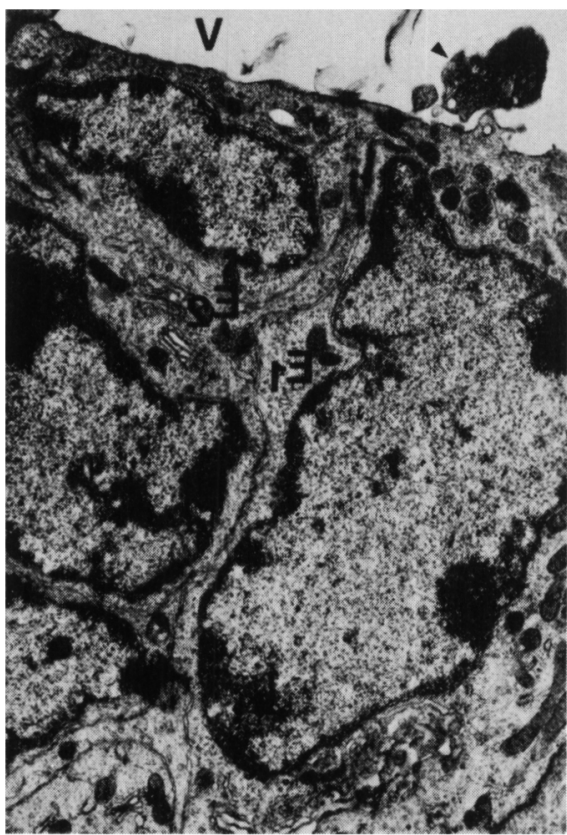

Figure 1. Common mural ependymal cells $\left(E_{1}, E_{2}\right)$ from the rabbit third ventricle (V) with large nuclei occupying a substantial part of the cell. The lateral surfaces of adjacent cells are without elaborate interdigitation. An isolated profile (arrowhead), possibly neuronal is present at the ventricular surface. lets about a central pair of fibers. Processes of contiguous ependymal cells (marginal folds) frequently overlap parts of the apical surface. Occasionally a variety of isolated profiles readily distinguishable from ependymal cells or their processes, are also encountered at the ventricular surface (Fig. 1). Some are compatable with ultrastructural descriptions of unmyelinated nerve fibers (re: section $4 \mathrm{i}$ ), others are not. A conspicuous round or oval nucleus, often eccentrically placed, occupies a substantial part of the ependymal cell. Its coarsely granular karyoplasm, containing a single nucleolus, is bound by the usual fenestrated double membrane. The cytoplasm has a pale, finely granular appearance, with dispersed agranular endoplasmic reticulum and numerous spherical to elongated mitochondria. Organelles and inclusions are principally confined to the apical cytoplasm of the cell, or along its lateral edge. Ribosomes, though dispersed throughout the cytoplasm in clusters or rosettes, are only infrequently associated with the

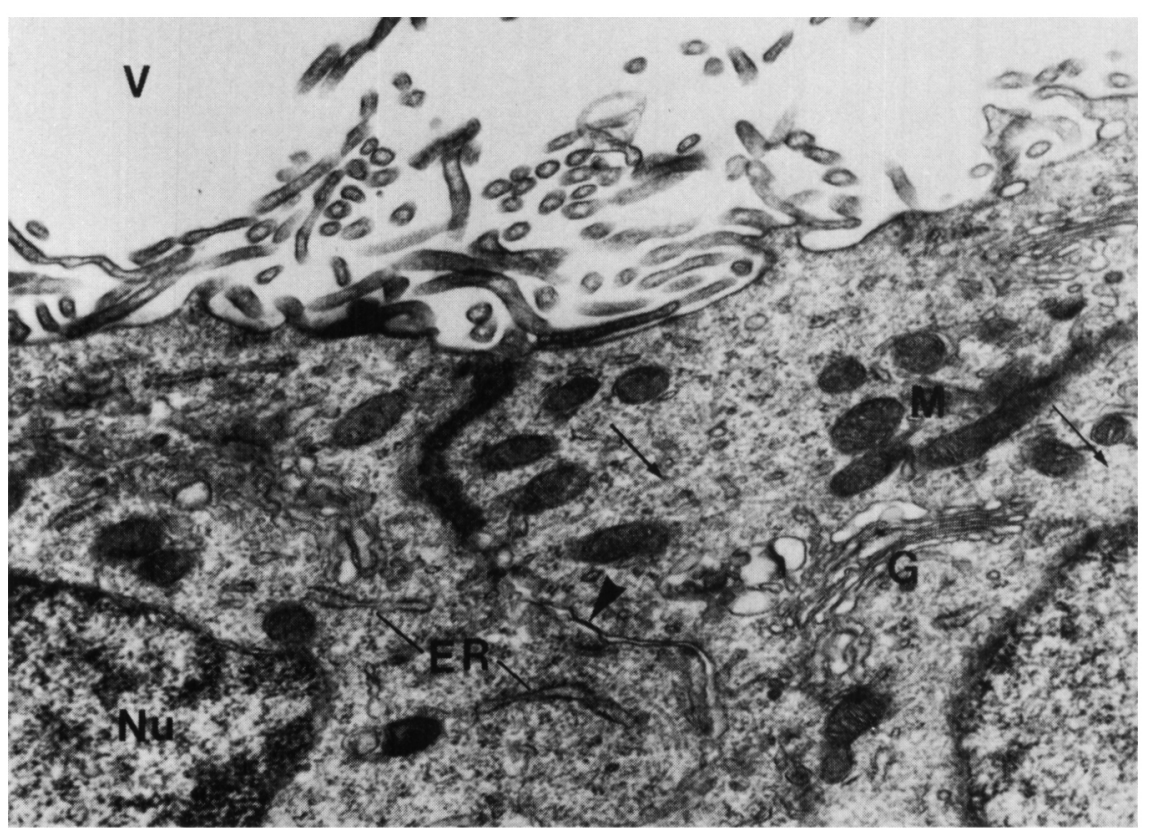

Figure 2. Supranuclear portion of cuboidal ependymal cells illustrating the abundance of juxtaventricular organelles and inclusions. The apical membranes bordering the third ventricle (V) are complexly organized into numerous microvilli-like projections and cilia (not present in the field shown). Along the lateral apices of contiguous cells, zonullae occludentes (arrowhead) and adhaerentes comprise the junctional complexes. (G), Golgi complex; (M), mitochondria; $(\mathrm{Nu})$, ependymal cell nucleus; (ER), rough endoplasmic reticulum; (arrows), microtubules. 
endoplasmic reticulum. The Golgi complex, with its typical complement of vesicles and cisternae generally occupies a supranuclear position (Fig. 2). Randomly dispersed cytoplasmic filaments and microtubules were frequently observed, however dense perinuclear bundles of filaments as demonstrated in the rat Brightman and Palay (1963), Millhouse (1972), were not evident. Membrane bound multivesicular bodies and lysosomes are also common.

The lateral surfaces of adjacent ependymal cells are without elaborate folds and interdigitations. A detailed report of the complex intercellular junctions between contiguous ependymal cells in the rat has been published Brightman and Palay (1963). Our observations are in substantial agreement with these findings. The principal types of junctional complexes encountered in the rabbit were zonulae adhaerentes and occludentes (Fig. 2). Typical desmosomes do not occur between ependymal cells. The basal surfaces of the ependymal cells are without elaborate plication or processes and lie directly on the underlying neuropil without an interposed basement membrane between them.

The ciliated cuboidal ependymal cells have been attributed various functions. Histochemical observations indicate that these are cells of high metabolic activity related to secretion, absorption or transport of substances from the vasculature into the ventricle or vice versa Nandy and Bourne (1964). In contrast, the enzymatic pattern has also been regarded as an expression of energy transformation associated with ciliary motility suggesting that to be the prime function Schachenmayer (1967).

In addition to the typical ependymal cell, a second cell type, the ependymal astrocyte Horstmann (1954), has been recognized as a component of the ependymal wall. Tennyson and Pappas (1962), identified it as a columnar cell with a branching peripheral process of light density within the ependymal lining of the fetal rabbit midbrain. A spar- sity of mitochondria, endoplasmic reticulum and filaments, complex plication of the lateral cell membrane, and multiple thin projections from the cell body and main process, were cited as its distinguishing features. In the feline lateral ventricle, the presence of a similar cell was ascribed to the subependyma Klinkerfuss (1964). The ependymal nature of these cells therefore is open to question. Similarly, "glandular" cells distinguished among the ependyma in the anterior tuber cinereum of the Rhesus monkey Knowles and Anand Kumar (1969), Anand Kumar (1972), Knowles (1972), cannot be categorized with certainty. They may correspond to the specialized ependyma described in the IR of the rat, Lévêque and Hofkin (1961), Lévêque, Stutinsky, Porte and Stoeckel (1966), and the ventral "glandular" ependyma and/or type 4 tanycytes of the quail, Sharp (1972). There are indications, however, that these cells may subserve a secretory capacity related to pituitary function.

The other principal cell variant distinguished within circumscribed areas of the ventricular wall is the ependymal tanycyte. Their presence has been demonstrated using a variety of histological and histochemical procedures Fleischhauer (1961), Anand Kumar and Knowles (1967), Bleier (1972), Sharp (1972). Ultrastructural studies have established that the tanycyte is a fundamentally distint cell with a single dense peripheral process that is generally unbranched except at its termination, corresponding to LM descriptions Tennyson and Pappas (1962), Leonhardt (1966), Brawer (1972), Millhouse (1972). Although clusters of such cells may be found scattered throughout the dorsoventral extent of the third ventricle, they are particularly numerous along the lateroventral walls and floor Knowles and Anand Kumar (1969), Millhouse (1971), Sharp (1972).

An electron micrograph of an ependymal tanycyte soma and the proximal part of its long irregular process is shown in Fig. 3. Tanycytes at this level of the rabbit third ventricle (along the lateral wall and floor of the IR) are furnished with very few cilia; rather their apical surfaces are characterized by an extensive elaboration of pleomorphic microvilli-like processes. Thesefindings are in accord with both earlier ultrastructural reports Matsui and Kobayashi (1968), Knowles and Anand Kumar (1969), Brawer (1972), and recent SEM observations (re: sections 3, 4) in a number of species. The apical lateral membranes between adjacent cells may or may not be interdigitated. They generally contain intercellular junctional complexes similar to those described in common mural ependyma. A paucity of occluding junctions occur however, between tanycytes in the arcuate region of the rat, Brawer (1972). The nuclei of rabbit tanycytes are elongate and often deeply indented with one or more nucleoli. The somata contain the normal complement of organelles and inclusions some of which extend into the proximal and distal portions of their processes. Dispersed within the cytoplasm are numerous ribosomes, dilated cisternae of smooth endoplasmic reticulum and isolated profiles of granular reticulum. Mitochondria are numerous, particularly in the basal cytoplasm, and throughout the processes. The Golgi complex is prominent and situated either supra or infranuclearly. Vesicles, multivesicular bodies and lysosomes are common features of the soma as are microtubules and filaments. Millhouse (1972), cited nuclear shape, matrix density and the absence of bands of filaments surrounding the nucleus as the principal criteria for distinguishing tanycytes in the rat. On the other hand, the cytology of rabbit ependymal cells was observed to be sufficiently similar to suggest that differentiation of cell types be determined by the morphology of their bases Tennyson and Pappas (1962).

The peripheral process of the tanycyte extends into the subjacent neuropil and is frequently directed toward a capillary wall. It characteristically has a dense appearance and contains numerous longitudinally oriented mitochondria, microtubules and filaments (Fig. 3, inset). Dilated cisternae and rosettes 
of ribosomes are also present. In the postnatal rabbit, the number of organelles were observed to diminish distally in the tanycyte processes Tennyson and Pappas (1962). In the rat, however, the small size and orientation of the mitochondria and the numerous highly oriented microtubules are diagnostic criteria for identifying tanycyte processes in the neuropil, Brawer (1972). There is no indication in the rabbit, as in the rat, Millhouse (1972), that the basal processes of tanycytes repeatedly branch to form a syncytium, Knowles and Anand Kumar (1969).

Although the cytological features of these cells and their relationship with other tissue components have been described in several reports, the criteria for identifying their terminal processes and distinguishing them from other processes in the neuropil remains uncertain. The tanycyte process is unbranched throughout its course, except at its termination where it divides into several slender branches. A pericapillary ependymal ending abutting directly on the basement membrane of a capillary perivascular space is shown in Fig. 4 . These tanycyte foot processes are reported to contain numerous microtubules and filaments, paraxiallyoriented mitochondria, vesicles and granules.

Although the precise function of tanycytes is far from clear, the literature is replete with conjecture, that will not be enumerated here. For a detailed discussion of several possibilities that have been advanced, the reader is referred to the work of Millhouse (1971), (1972). Indeed, recent morphological and cytochemical observations have even indicated structural and possibly functional differences among tanycytes themselves Luppa and Feustel (1971), Millhouse (1971), Sharp (1972). Only the available evidence relating to the possible neuroendocrine function of those tanycytes which contact the portal vasculature will be presently reviewed (re: section 6).

3. Structure of the Tanycyte and its Vascular Termination: Scanning Electron Microscopy

Although the scanning electron

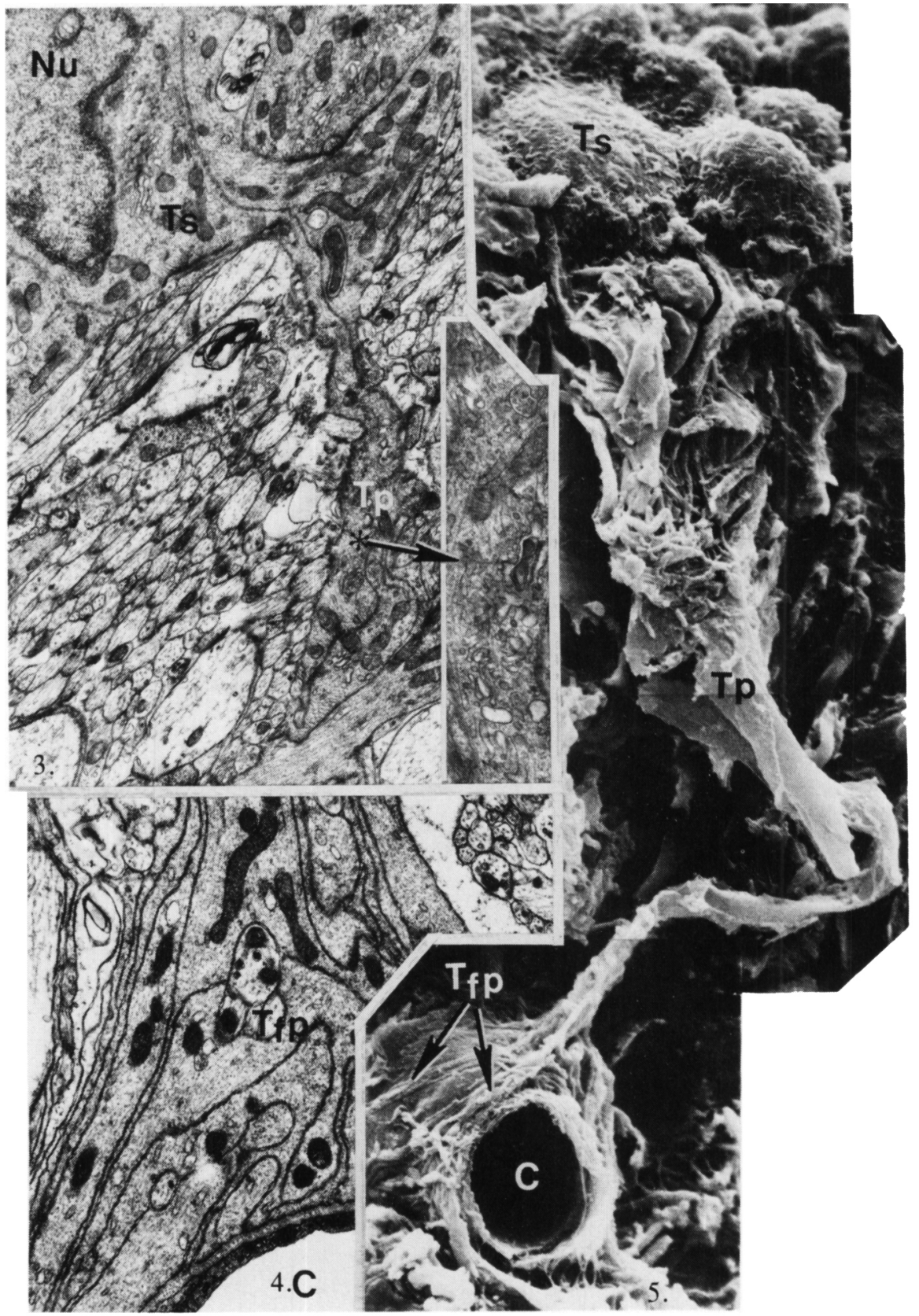

Figure 3. Transmission electron micrograph of an ependymal tanycyte soma (Ts) and the proximal part of its basal prolongation (Tp) along the ventrolateral wall of the rabbit IR. ( Nu), tanycyte nucleus.

$\times 9,200$

Inset, basal process of the tanycyte containing microtubules and filaments, mitochondria, ribosomes and smooth endoplasmic reticulum. $\quad$ X 20,000

Figure 4. Median eminence (external layer) illustrating the direct apposition of a tanycyte foot-process ( $\mathrm{Tfp}$ ) on the basement membrance of a capillary (C) perivascular space.

$\mathrm{X} 13,600$

Figure 5. Scanning electron micrographs arranged as a montage illustrating the three dimensional structure of an ependymal tanycyte at the level of the rabbit IR. The luminal surface of the soma (Ts) is nonciliated and its single tapering process ( $T p$ ) is unbranched throughout its course through the $M E$ except at its termination where multiple endfeet (Tfp) are given off. (C), capillary ( 9 diam.). $\times 2,700$ 
microscope (SEM) has been employed in morphological investigations of ependyma lining the mammalian cerebral ventricles, its use has largely been restricted to a regional topographical analysis of surface specializations. Such investigations, particularly of the third cerebral ventricle, have demonstrated regional differences in the surface of the ventricle walls consistent with the pattern of tanycyte distribution demonstrated in light microscopic (LM) and transmission electron microscopic (TEM) investigations of equivalent ventricular areas, and with their functional specialization (re: sections $2,4,6$ ). Using the SEM only, it has not been possible to distinguish tanycytes from ordinary ependymal cells from a topographical analysis of their surface. We have attempted to demonstrate, therefore, the three-dimensional structure of the tanycyte and its hypophysial portal vascular termination with the SEM and to correlate these observations with the appearance of their surface. Such a study has not to our knowledge been undertaken previously.

Our observations were restricted to the non-ciliated region of the rabbit third ventricle at the level of the IR. The intricate structural relationship established between an infundibular ependymal cell process and a blood vessel of the hypophysial portal system as viewed with the SEM is shown in Fig. 5. The cell body is rounded in shape (9-12 4 mdiam.) and its apex protrudes into the ventricular lumen. The luminal surface is non-ciliated with numerous irregular blebs or microvilli-like evaginations of the plasmalemma in accord with previous TEM and SEM descriptions (re: section 2 and 4). Occasionally more elongate flask-shaped tanycyte somata were also discernible. A single long $(0.1 \mathrm{~mm})$ thick process extends from the base of the tanycyte soma into the subjacent neuropil. This transition from cell body to tail process was often clearly definable, although this region was also often obscured by numerous interwoven processes whose origin could not be determined. The tail process is smooth and uniform throughout its extent, tapering (3.0-1.5 $\mu$ mdiam.) as it approaches the blood vessel. Although it appears unbranched throughout its course, the process divides at its termination into several slender branches (0.1-0.4 $\mathrm{Lm}$ miam.) which entwine about the vessel and terminate as small foot processes. This investigation, in examining the morphology of the tanycyte in three dimensional perspective, demonstrates its close conformity to LM and TEM descriptions. It also supports the inference of earlier SEM investigations that the modified ependymal cells distinguished in this region of the ventricle are specialized ependymal tanycytes.

\section{Morphology of the Ependy-} mal Lining of the

Mammalian Third Ventricle:

Scanning Electron Microscopy

Scanning electron microscopy has been increasingly employed in recent years to examine the morphological features of the ependyma lining the third cerebral ventricle in several mammalian species. Knigge and Scott (1970), initially reported ependymal specializations within the area of the rat IR consistent with available

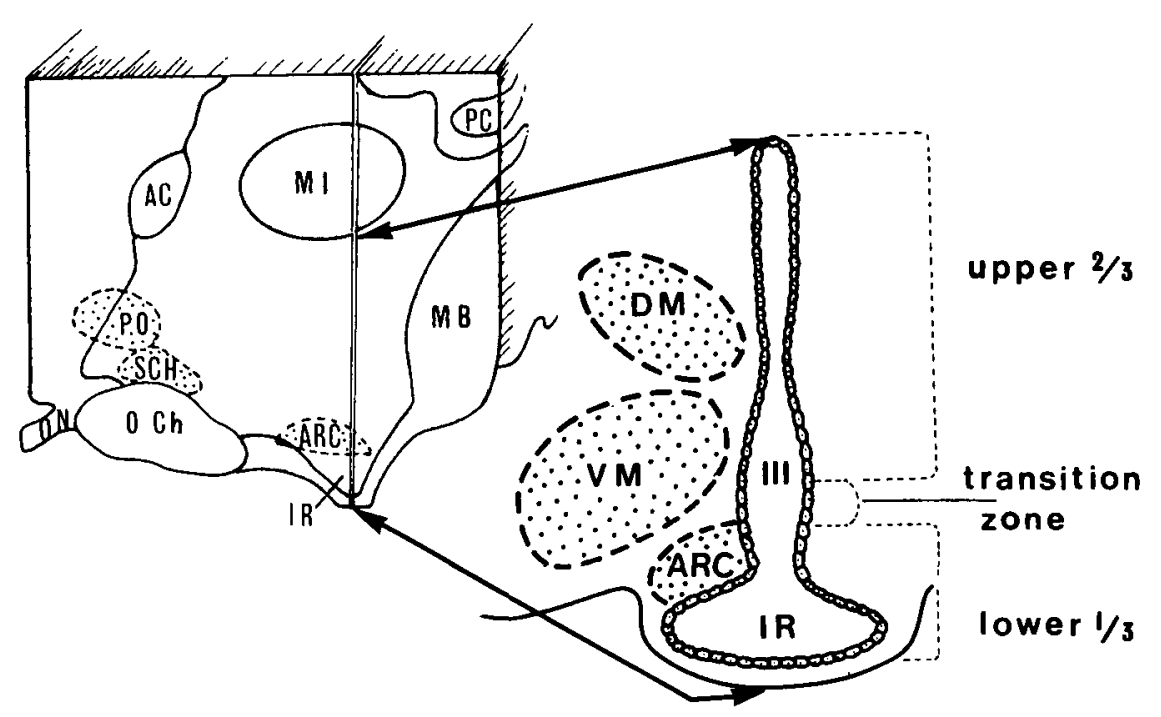

Figure 6. Diagrammatic representation of the excised diencephalic block showing the entire rabbit third ventricle in mid-sagittal section as viewed with the SEM, and a coronal section through the middle hypothalamus illustrating the divisions of the ventricular surface and the relative position of the underlying hypothalamic nuclei. (AC), anterior commissure; (MI), massa intermedia; (OCh), optic chiasma; $(\mathrm{ON})$, optic nerve; (MB), mammillary body; (PC), posterior commissure; (IR), infundibular recess; $(\mathrm{PO})$, preoptic nucleus; $(\mathrm{SCH})$, suprachiasmatic nucleus; (ARC), arcuate nucleus; (DM), dorsomedial nucleus; (VM), ventromedial nucleus; (III), third ventricle. 
in mid-sagittal section precisely as viewed with the SEM is provided in Fig. 6. The third ventricle can be conveniently divided into three regions on the basis of observed variation in the structural features of the ependymal surface. These divisions and the relative position of the underlying hypothalamic nuclei are illustrated in coronal section in the same figure.

In the rabbit, the upper two-thirds of the ventricular wall is lined by ependymal cells with a profusion of cilia that extend into the lumen of the ventricle; non-ciliated ependymal surface is infrequently observed (Fig. 7). This type of surface extends from

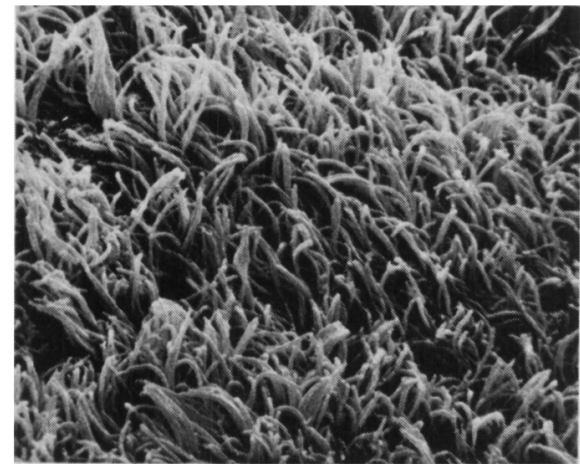

Figure 7. Scanning electron micrograph of the upper two-thirds of the luminal surface of the rabbit third ventricle. A profusion of long cilia extend into the lumen of the ventricle; only a few non-ciliated areas are observed.

X 2,800

the lamina terminalis and anterior commissure to the cerebral aqueduct caudally. Cilia project from the surface of each ependymal cell in clusters which often appear oriented in parallel longitudinal rows. In contrast, a transition in the morphology of the luminal ependymal surface occurs at about the level of the underlying ventromedial nucleus (Fig. 8). Cilia occur less frequently, and nonciliated ependymal cells predominate. The latter are generally rounded in shape, with their apices protruding into the ventricular lumen forming a smoothly contoured surface. Their juxtaventricular surface is characterized by the presence of numerous small knob- or bleb-like protrusions of the plasmalemma. The substructure of individual cilia can be seen to greater advantage in this

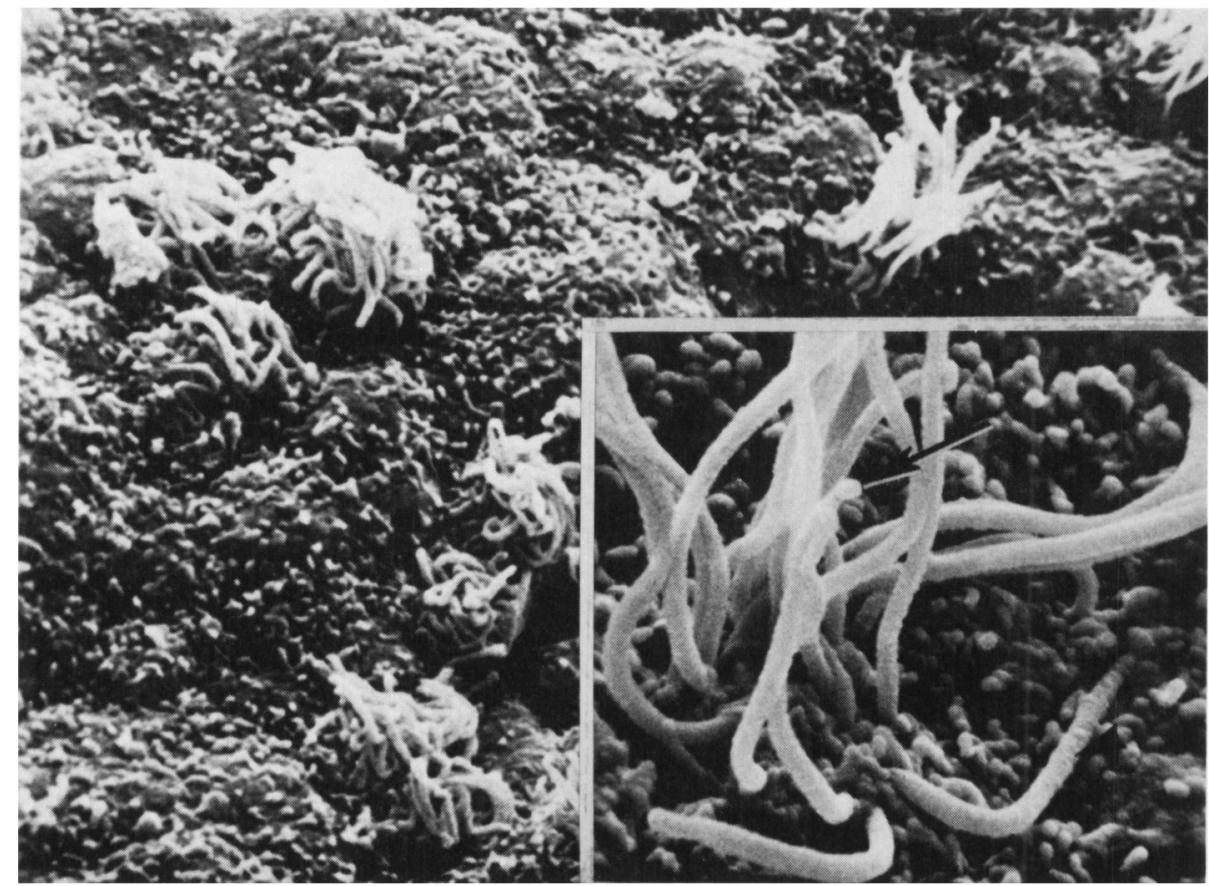

Figure 8. Lower one-third of the rabbit ventricular wall. a transition in the morphology of the ependymal surface can be seen. Ciliated cells occur less frequently and non-ciliated ependymal cells predominate. They are rounded in shape and their apices protrude into the ventricular lumen, forming a smoothly contoured surface.

X 3,200

Inset, about 25 cilia are seen to extend in a cluster from the ependymal surface. The diameter of the ciliary shaft tapers toward the tip, terminating in a bulbous enlargement (arrow). The ciliary surface is irregular and almost segmental in appearance (arrowhead).

X 6,600

region because of the infrequency with which they occur. Generally, clusters of 25 or more cilia originate from the apical surface of a single ependymal cell and project into the ventricle (Fig. 8, inset). Unlike the cat, Clementi and Marini (1972), the diameter of the cilium is not constant from base to tip, rather the individual cilia in the rabbit taper distally, terminating in a bulbous enlargement. Similar surface specializations (ciliary crowns) have recently been demonstrated in the cilia of mouse oviduct with both the scanning and transmission electron microscope Dirkson and Satir (1972).

In the sheep, Kozlowski, Scott and Dudley (1973), monkey, Coates (1973a, b), and the mink, Scott, Kozlowski and Dudley (1973) there is also a terminal dilatation of the apex of each cilium, the diameter of which exceeds that of the ciliary shaft. The ciliary surface in the rabbit, however, is irregular and almost segmental in appearance, unlike that of either the mink, Scott et al (1973), or the cat,
Clementi and Martini (1972), which possess smooth profiles without particular substructure. Such morphology may reflect a means of extending the surface area for purposes of ciliary pinocytosis Brightman (1965). Occasionally, periciliary moats as described by Kohno and Usui (1966), could also be seen surrounding the base of each cilium at the cell surface. For a detailed discussion of the structure and function of cilia, the reader is referred to the following reports: Brightman and Palay (1963), Worthington and Cathcart (1963), Cathcart and Worthington (1964), Kohno and Usui (1966), Dalen, Schlapfer and Mamoon (1971).

The lower one-third of the ventricular wall, represented by an area along the floor and lateral walls of the IR (Fig. 9), is devoid of cilia except for the occasional individual cilium. The most consistent structural feature is the undulating non. ciliated ependymal surface and the presence of numerous irregular sur- 


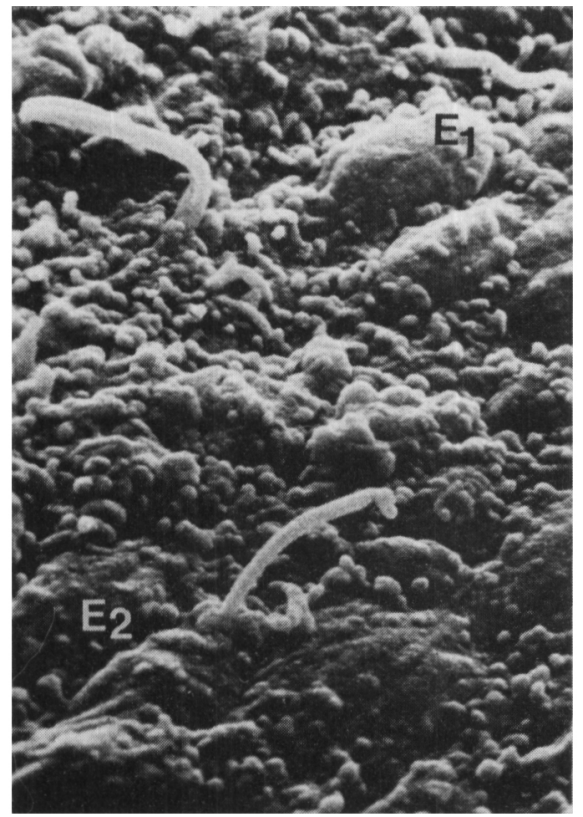

Figure 9. Along the floor and lateral walls of the rabbit IR, only occasional single cilia are seen. The characteristic feature of this region is the large undulating non-ciliated ependymal surface with its numerous irregular surface blebs or knob-like protrusions. $\left(E_{1}, E_{2}\right)$, ependymal cells.

X 5,200

face blebs or knob-like protrusions. This distinct regional variation in the morphology of the ependymal surface is consistent with both SEM Scott, Dudley, Gibbs and Brown (1972), Scott, Paull and Dudley (1972), and ultrastructural observations Tennyson and Pappas (1962), Brightman and Palay (1963), Klinkerfuss (1964), Rinne (1966), Anand Kumar (1968), Malinsky (1968), Knowles and Anand Kumar (1969), in a number of species. It is evident that this regional specialization of ependymal structure may be suggestive of a difference in functional capacity. Although as yet largely unconfirmed, the contention is that the ependyma, particularly in the region of the IR, exhibit the classical morphological features of an actively absorptive, secretory and/or transportive epithelium (re: sections 2, 6).

\section{i) Intraluminal Neuronal Processes}

The presence of biologically active compounds has been demonstrated in the cerebrospinal fluid Lurie and Weiss (1967), Margolis and Altszular (1967), Anand Kumar and Thomas (1968), Bagshawe, Hillary, Orr and
Rushworth (1968), Heller, Hasan and Saifi (1968), Vorherr, Bradbury, Hoghougi and Kleeman (1968), Linfoot, Garcia, Wei, Fink, Sarin, Born and Lawrence (1970), SiersbaekNielsen and Molholm Hansen (1970). In addition to the supposition that ependyma may discharge similar substances into the CSF, intraventricular neuronal processes have also been considered a potential mode of entry for active principles and have recently received considerable attention. Both light microscopic and transmission electron microscopic investigations have demonstrated the presence of CSF contacting neurons within the ventricular lumen of numerous vertebrates. Bulbshaped CSF contacting nerve terminals projecting between ependymal cells have been described in the third ventricle of fish, Oztan (1967), VighTeichmann, Vigh and Koritsanszky (1970a). The occurrence of typical dense-core vesicles in these cell processes and their topographical arrangement indicate that they arise from neurosecretory cells and probably secrete into the ventricle. Similar neurons with ventricular processes projecting from the ependymal lining into the third ventricle have also been demonstrated in amphibians, Dierickx (1962), Smoller (1965), Peute (1969), and reptiles Ito (1965), Vigh-Teichmann et al $(1970 \mathrm{~b}, \mathrm{c})$. Analogous nerve terminals are also present in the central canal of the amphibian and avian spinal cord Vigh, Vigh-Teichmann and Aros (1970), Vigh, Vigh-Teichmann, Koritsanszky and Aros (1971). Isolated profiles arising from nerve cells lying in the subependymal tissue are also encountered both at the ependymal surface and closely interdigitated with ependymal cells in the rat, Brightman and Palay (1963), Mitro (1969). Fox, DeSalva, Zeit and Fisher (1948), ascribed a receptor function to similar fiber endings in the monkey third ventricle. Matsui and Kobayashi (1968), however, have suggested that unmyelinated axonal endings which protrude into the third ventricle are only found infrequently in the rat. On the other hand, intraventricularly-lying myelinated neuronal endings have been found in the Inouse IR Wittkowski (1959). In the third and fourth ventricles of the rabbit and cat brain, bulb-like processes of nonmyelinated nerve fibers have been described Leonhardt and I indner (1967), Leonhardt (1968), L eonhardt and Prien (1968), I,eonhardt and Backhus-Roth (1969). The processes contain both the small clear, synaptic-type vesicles and larger densecore vesicles, as well as quite distinctive large mitochondria. Between the plasmalemma of the bulb and the apical plasmalenma of the ependyma, desmosome-like junctions and synapse-like contacts are found. Not all cell processes seen at the luninal surface therefore belong to ependymal cells. Distinct bleb-like protrusions or irregularities of the free surface seen consistently along the lower wall of the third ventricle with the scanning electron microscope, may be homologous with the neuronal projections between ependymal cells from underlying nerve cells as documented by L.M and TEM. Alternatively, many or all of the surface specializations may in fact be cytoplasmic protrusions of the ependymal plasmalemma itse.lf, similar to those described in the rat and sparrow, Matsui and Kobayashi (1968), Usui (1968).

The presence of a variety of supraependymal structures have also been reported in the mammalian cerebral ventricles Schwanitz (1969). In some species, glial cells lie freely in the ventricle Leonhardt and Lindner (1967), while in others, microglial-like "spider" cells lie on the ependymal surface Bleier (1971) (1972). Nerve fibers situated supraependymally have also been found Fox et al (1948), Westergaard (1972). Recently the presence of curious supraependymal cells with branching processes within the ventricles of a number of species have been confirmed by several authors using the SEM. It is speculated that they may represent intraluminal neuronal processes, although at present the precise nature and function of these conceivable neuronal elements is obscure. Cleinenti and Marini (1972), using SEM techniques, described numerous small round formations on 
the floor of the cat third ventricle morphologically similar to the clublike liquor contacting nerve endings demonstrated in the TEM investigations of Vigh-Teichmann et al (1970b). Distinct projections of underlying neural tissue were not observed, however, in SEM investigations of the ependyma in the lateral ventricles of sheep, Kozlowski, Scott and Murphy (1972). Cellular elements with branching processes that could be interpreted as nerve cells were also found in the cat third ventricle Clementi and Marini (1972), as well as on the ependymal surface of the squirrel monkey organon vasculosum and in the basal hypothalamus of the rabbit, Weindl and Joint (1972a, b). Multi-processed conceivably neural supraependymal cells have also been consistently observed along the floor and at sites in the IR of the monkey, Coates (1972), (1973a, b), mink, Scott et al (1973), and human, Scott, Paull and Dudley (1972), third ventricle. Previous SEM investigations conducted in this laboratory have failed to document the presence of supraependymal neurons within the third ventricle of any species examined Bruni et al (1972), (1973). Recently however, we have observed supraependymal structures with many long branching processes extending over the underlying ependymal surface in the rabbit third ventricle. Although these elements may be conceivably construed as neuronal, their occurrence was restricted to the rabbit where they were seen only infrequently. The extent of the intraluminal structures is shown in Fig. 10a. They were situated along the non-ciliated antero-lateral wall of the rabbit IR. Oval or spherical shaped cell bodies with a relatively smooth texture were particularly conspicuous (Fig. 10d). Generally, a single thick branching process extends from the cell body over the ependymal surface. Bifurcating processes, many of which seemed to extend into the underlying ependymal surface, could often be traced for their entire length (Fig. 10b). Frequently, processes were interwoven at their termination in a tangled synapse-like contact with a similar

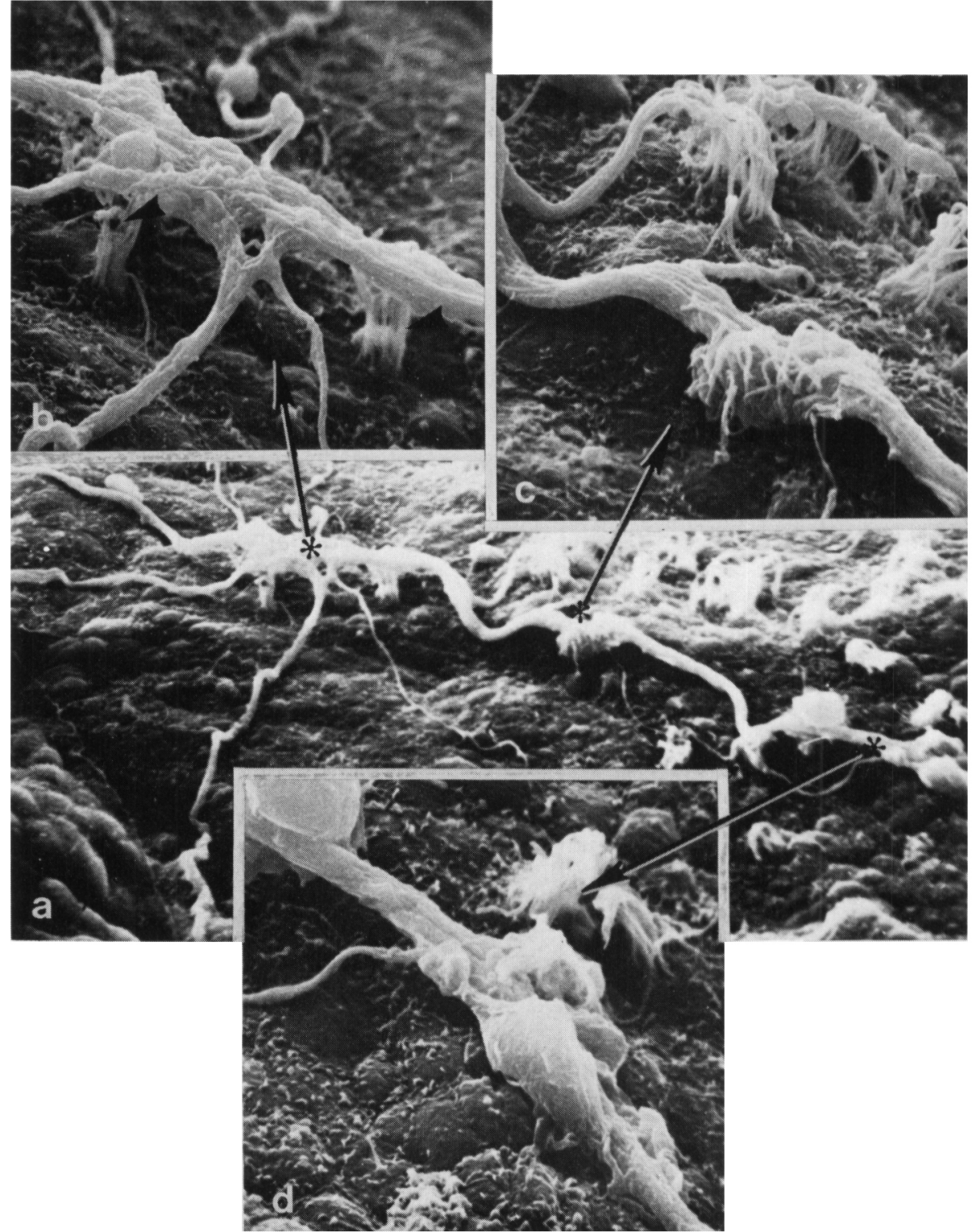

Figure 10. (a) Scanning electron micrograph of the antero-lateral wall of the rabbit IR. Occasionally, supraependymal structures with long branching processes were seen lying on the non-ciliated ependymal surface of the recess. $X 700$. (b) bifurcating processes were often observed to extend into the underlying ependymal surface (arrowheads). X 1,600. (c) frequently, processes were interwoven at their termination in a tangled synapse-like contact. $X 1,760$. (d) most processes were observed to originate from oval or spherical shaped cells with a relatively smooth texture.

X 1,800

process originating from another supraependymal cell (Fig. 10c). Although it is not possible to establish the neuronal nature of these structures with the SEM, comparative TEM investigations support this supposition Noack et al (1972), Westergaard (1972). Nevertheless, in view of the inconsistency with which we have observed such structures, and their frequently observed continuity with the cut surface of the tissue, the possibility of preparational artifact cannot be precluded. Therefore, cautious interpretation of such SEM observations is warranted. At present, direct evidence for functional roles, classification, precise origin or detailed course of these supraependymal cells is lacking. It has been assumed, however, that such cells may be capable of regulating the functioning of ependymal cells, that they may be involved in 
neuroendocrine regulating mechanisms, or subserve a phagocytic, receptor or secretory function.

\section{Application of Silver Nitrate Staining to Scanning Electron Microscopy of Ependyma}

A corollary of our earlier SEM investigations was to establish a means of identifying and delineating individual ependymal cells, thereby recognizing cell patterns and differentiating them from other structures. The present study therefore investigated the extent to which the classical silver technique could be successfully adapted to the study of ventricular ependyma. Microscopic studies on ependymal cell boundaries following treatment with silver nitrate have not been undertaken previously.

Silver nitrate staining itself, however, is an old histological technique used to demonstrate endothelial and epithelial cell boundaries 'en face'. Recent studies have endeavoured to establish the significance of the silver lines Florey, Poole and Meek (1959), and the mechanisms involved in silver staining Gottlob and Hoff (1968). The suitability of silver nitrate staining for demonstrating aortic endothelial cell borders with the SEM was shown by Garbarsch and Christensen (1970). More recently Geissenger (1972), also reported the use of the SEM in investigations of arterial intima following impregnation with silver nitrate.

Details of the procedure used to prepare specimens for both SEM and comparative light and transmission electron microscopy have been reported Bruni et al (1973). Wholemount preparations of the rabbit third ventricle, viewed from the surface with the light microscope show a clear and uniform network of intercellular lines (0.3-0.5 $\mu$ mthick) imparting a characteristic mosaic appearance to the ventricular ependyma (Fig. 11). A continuous silver deposit marks the borders of irregular or polygonal cells that vary greatly in both size (4-12um diam.) and shape. The long axis of the ependymal cells in the region of the cerebral aqueduct and of the interven-

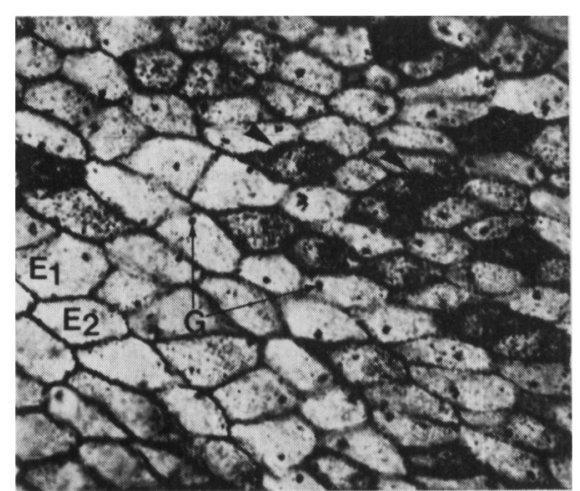

Figure 11. Wholemount preparation of rabbit third ventricle. A uniform network of intercellular silver lines mark the borders of irregular or polygonal ependymal cells $\left(E_{1}, E_{2}\right)$ that vary in both size and shape. Individual ependymal cells exhibit a differential affinity for the stain (arrowheads). Note the prominent Golgi complex $(G)$ which occupies a supranuclear position within each cell. Lines stained with silver nitrate, nuclei stained with Harris hematoxylin.

$X 2,050$

tricular foramen appears to parallel the axis of these structures. In contrast, the cells elsewhere in the third ventricle are more rounded than elongate and do not exhibit any specific orientation. In addition, individual ependymal cells and groups of cells exhibit a differential affinity for the stain, indicative perhaps of the structural and possibly functional differences reported among ventricular ependyma Schachenmayer(1967), Knowles and Anand Kumar (1969), Luppa and Feustel (1971), Millhouse (1971), Sharp (1972). A prominent nucleus, deeply situated and eccentrically placed, was visible when the specimens were optically sectioned. The ubiquitous presence of a black dot which occupies a supranuclear position within each cell suggests that this might well represent the Golgi complex.

As viewed with the SEM, the ependymal cells showed exactly the same distinct outlines (Fig. 12) which had been observed previously 'en face' with the light microscope. The most notable feature is the appearance of the silver lines, which are much lighter and stand out from the rest of the tissue. The particles of silver gave rise to a higher emission of sec-

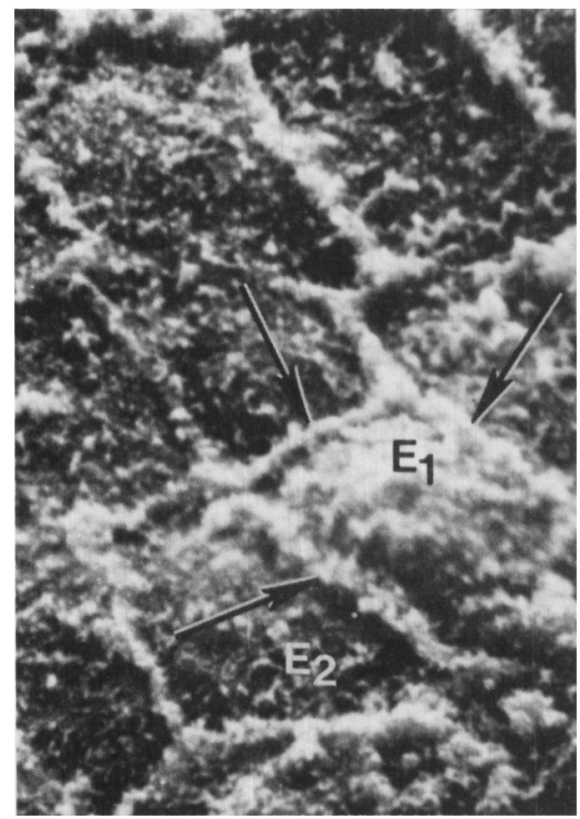

Figure 12. Scanning electron micrograph of silver nitrate-impregnated rabbit third ventricle. The ependymal cells show the same distinct outlines as observed 'en face' with the light microscope. The apices of the nonciliated ependymal cells ( $\left.E_{1}, E_{2}\right)$ protrude into the ventricular lumen. On each cell, knob- or microvilli-like specializations of the ependymal surface can be seen. Their intercellular boundaries are delineated by elevated silver deposits (arrows) which are lighter and stand out from the rest of the tissue.

$\times 6,300$

ondary electrons in material examined with the SEM and, therefore, it is possible to detect silver lines relative to the surrounding tissue by virtue of the fact they appear brighter Daniel (1969), Geissinger (1972). The non-ciliated ependymal cells are polygonal, their apices protrude into the ventricular lumen, and the intercellular boundaries of individual cells are marked by distinct, elevated silver deposits of a coarse granular nature. On the surface of each ependymal cell, small rounded elevations are seen, some of which undoubtedly represent knob- or microvilli-like protrusions of the cell surface; others probably represent small silver grains.

Comparative TEM studies of silvered ependyma viewed in crosssection, complement observations made with the LM and SEM. Silver deposits in the intercellular space 


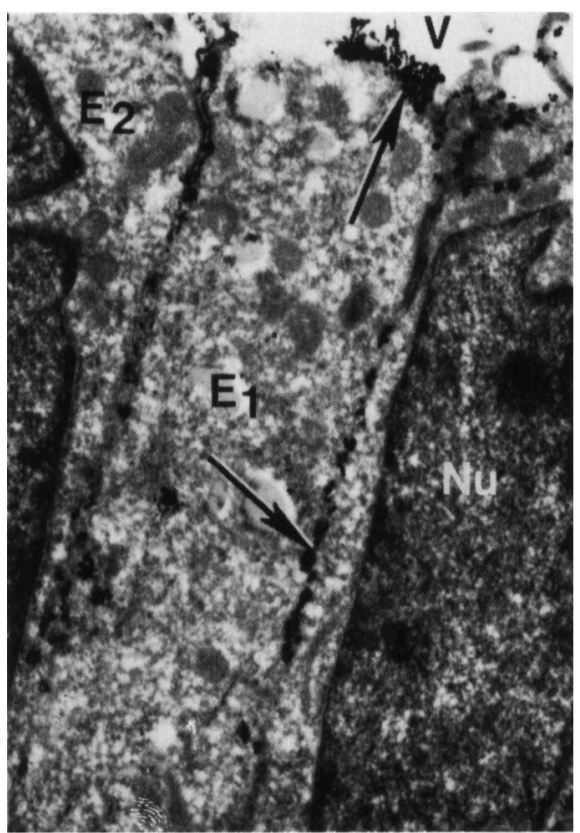

Figure 13. Transmission electron micrograph of ventricular ependyma in the rabbit after staining with silver nitrate. Silver deposits along the entire lateral interspace between adjacent ependymal cells $\left(E_{1}, E_{2}\right)$ and randomly distributed silver particles can also be seen on the juxtaluminal surface (arrows). (V), third ventricle; $(\mathrm{Nu})$, ependymal cell nucleus.

X 14,400

between adjacent ependymal cells and randomly distributed silver particles can also be seen on the cell surface (Fig. 13). Silver particles were often deposited along the entire lateral interspace as far basally as the subependyma and interstices of the neuropil below.

This investigation provides evidence of the suitability of silver nitrate as a LM and SEM stain for demonstrating ventricular ependymal cell boundaries. Although it is not yet possible to unequivocally distinguish preparational artifact from the in vivo life-like state, the use of silver nitrate in this connection nevertheless, does permit convenient identification of individual ependymal cells and their differentiation from one another and from other structures.

\section{Ependyma in Relation \\ to Neuroendocrine Function}

Although the existence of specialized ependymal cells within circumscribed regions of the ven- tricular wall has long been recognized, their possible neuroendocrine involvement, however, has been the focus of interest only in recent years. Since Lofgren (1959) (1960), initially suggested that ependymal cells and CSF of the third ventricle may be involved in the regulation of adenohypophysial activity, much evidence of functional involvement has subsequently been adduced. Secretion by certain specialized ependyma into the CSF of the third ventricle has been described by many investigators Lévêque and Hofkin (1961), Vigh, Aros, Wenger, Koritsanszky and Cegledi (1963), Vigh (1964), Lévêque et al (1966), Knowles (1967), Matsui and Kobayashi (1968), Wittkowski (1969), Kobayashi Matsui and Ishii (1970). On the other hand, the concept of tanycytes absorbing substances from the CSF and/or subserving a transport capacity has also been postulated Anand Kumar and Knowles (1967), Knowles and Anand Kumar (1969), Knigge and Scott (1970), Kobayashi et al (1970), Kobayashi (1972), Kobayashi, Wada and Uemura (1972). Apart from these theories, correlations between pituitary activity and ependymal cell morphology have also been documented. Lévêque and Hofkin (1962) observed that gonadectomy, adrenalectomy, hypophysectomy and cortisone treatment had no effect on the content of PAS-positive material in the ependymal cells of the rat IR. Cold-stress and propylthiouracil-treatment however, increased and decreased their content respectively. In the Rhesus monkey, changes in ependymal tanycyte morphology have been associated with age, sex, reproduction and estrogen administration Anand Kumar and Knowles (1967), Anand Kumar (1968), Knowles and Anand Kumar (1969). Similarly, seasonal changes in ependymal morphology associated with sexual activity have also been demonstrated in the skunk, Hagedoorn (1965). It has been suggested that ependymal cells might be involved in the production and/or transport of pituitary releasing factors Knigge and Scott (1970), Scott and Knigge (1970), Anand
Kumar (1972), Knowles (1972), Lévêque (1972). The demonstration of neurohormones in the ventricular CSF Heller et al (1968), Vorherr et al (1968), Dencken and Haggendal (1969), Heller (1969), Linfoot et al (1970), Pavel and Coculescu (1972), and the transfer of active principles from the ventricle to the portal blood and pituitary Kendall, Grimm and Shimshak (1969), Knigge and Silverman (1972), Ondo, Mical and Porter (1972), Schecter and Weiner (1972), Ondo, Eskay, Mical and Porter (1973), indicates that ependymal mediation cannot be discounted. On the other hand, the questionable physiological significance of such a system Weiner, Blake and Sawyer (1971), Weiner, Terkel, Blake, Schally and Sawyer (1972), Gordon, Bolinger and Reichlin (1972), and the identification of hypothalamic sites of origin of releasing factors, other than ependymal Clattenburg, Singh and Montemurro (1971), 1972), Motta, Piva, Tima, Zanisi and Martini (1971), Tima (1971), casts some doubt on this supposition.

i) Effects of Ovariectomy on Ependyma

Kobayashi and Matsui (1969), and Kobayashi et al (1970), reported that 3 weeks after ovariectomy, most ependymal and hypendymal cells of the rat $M E$ were enlarged and became cylindrical; their nuclei were also enlarged and cytoplasmic organelles were prominently increased in number. However, cytoplasmic protrusions and microvilli on the apical surface of the ependymal cells were poorly developed. Comparable results have been observed by Oksche, Zimmerman and Oehmke (1972) in a morphometric analysis of ependymal activity in the mouse arcuate nucleus and ME following ovariectomy. In contrast, Knowles and Anand Kumar (1969) reported striking regressive changes in the ventricular border of tanycyte ependyma and in their contents 2 months following ovariectomy in the Rhesus monkey. Subsequent estrogen administration, noticeably increased the number of cytoplasmic protrusions and bulbous projections of the juxtaventricular surface. 


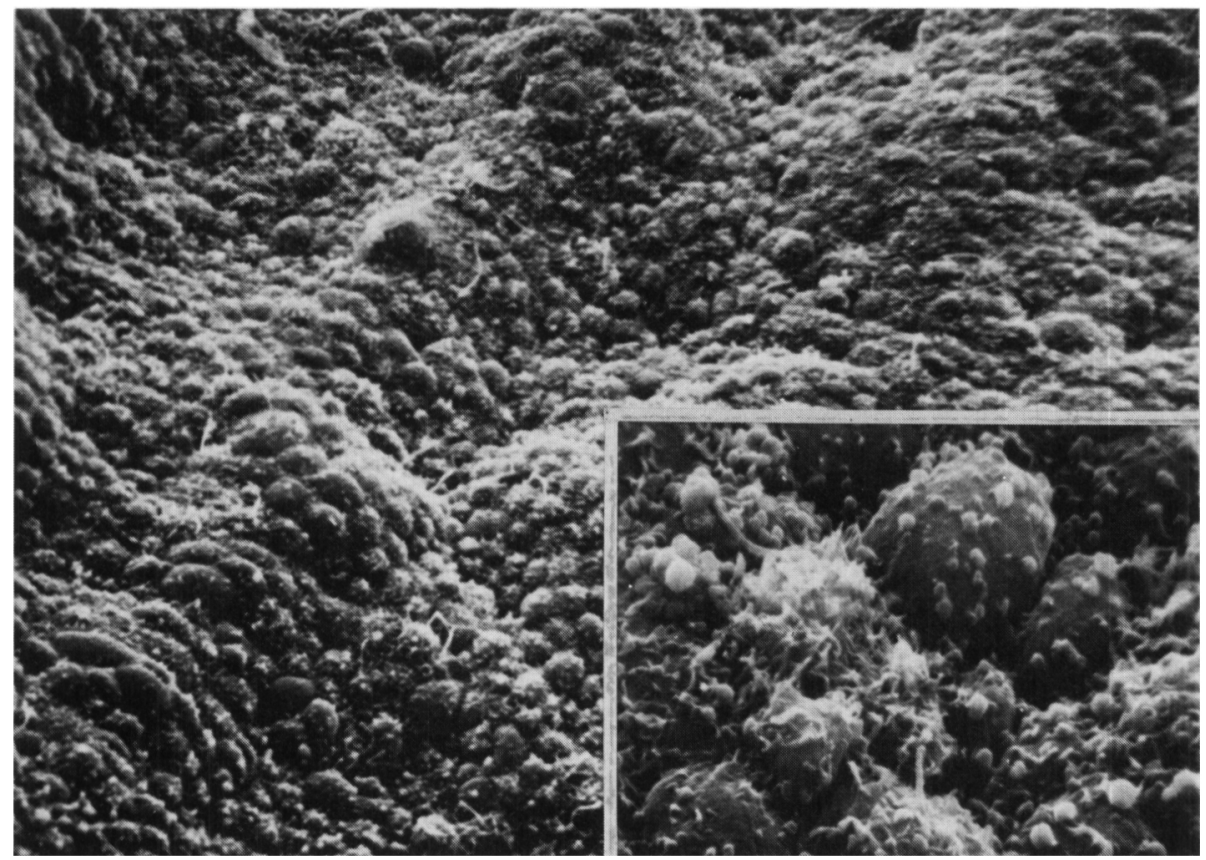

Figure 14. Scanning electron micrograph of the lateral wall of the rabbit IR three weeks after ovariectomy. The ependymal surface is irregular; individual ependymal cells are distinct, and appear enlarged and cylindrical.

X 780

Inset, increased numbers of bleb-like protrusions and finger-like microvilli of various shapes are observed on the surface of each ependymal cell.

X 3,300

In a series of experiments conducted in this laboratory, the morphology of the ependymal surface along the ventrolateral wall and floor of the rabbit third ventricle was examined with the SEM following ovariectomy. In normal females, the non-ciliated ependymal cells of this region are rounded in shape, and their juxtaventricular surface protrudes into the lumen forming a smoothly contoured surface (Fig. 8). Their apical surface is interrupted by small irregular knob- or bleb-like protrusions of the plasmalemma (Fig. 9). From 3 days to 34 weeks after ovariectomy however, this surface became more irregular; individual ependymal cells appear enlarged and cylindrical (Fig. 14). These morphological findings are consistent with the ultrastructural descriptions of Kobayashi and Matsui (1969), Kobayashi et al (1970), Oksche et al (1972). Individual ependymal cells are distinct and, in contrast to previous reports, increased numbers of bleb-like protrusions and finger-like microvilli with various shapes are observed on the ependymal surface (Fig. 14, inset).
Although the functional implications of these morphological findings are uncertain, they have been interpreted to indicate an enhancement of ependymal absorption, secretion, and transport to the primary portal capillaries.

\section{REFERENCES}

AGDUHR, E. (1932). Chorioid plexus and ependyma. In Cytology and Cellular Pathology of the Nervous System, pp. 537-573. Edited by W. Penfield. P. B. Hoeber Inc.: New York.

ALLEN, D. J., and LOW, F. N. (1973). The ependymal surface of the lateral ventricle of the $\mathrm{dog}$ as revealed by scanning electron microscopy. American Journal of Anatomy, $137,483-489$.

ANAND KUMAR, T. C. (1968). Sexual differences in the ependyma lining the third ventricle in the area of the anterior hypothalamus of adult Rhesus monkeys. Zeitschrift für Zellforschung und Mikroskopische Anatomie, 90, 28-36.

ANAND KUMAR, T. C. (1972). Neuroendocrine regulation of sexual cycles and ovulation in non-human primates. In symposium on the Use of Non-Human Primates in Research on Human Reproduction, pp. 152-169. Edited by E. Diczfalusy, and C. C. Standley. WHO Research and Training Centre on Human Reproduction: Stolkholm.

ANAND KUMAR, T. C., and KNOWLES, F. (1967). A system linking the third ventricle with the pars tuberalis of the Rhesus monkey. Nature, 215, 54-55.

ANAND KUMAR, T. C., and THOMAS, G. H. (1968). Metabolites of $3 \mathrm{H}$-oestradiol-17 beta in the cerebrospinal fluid of the Rhesus monkey. Nature, 219, 628-629.

BAGSHAWE, K. D., HILLARY ORR, A., and RUSHWORTH, A. G. J. (1968). Relationship between concentrations of human chorionic gonadotrophin in plasma and cerebrospinal fluid. Nature, 217, 950951.

BLEIER, R. (1971). The relations of ependyma to neurons and capillaries in the hypothalamus: A Golgi-Cox study. Journal of Comparative Neurology, 142, 439-463.

BLEIER, R. (1972). Structural relationship of ependymal cells and their processes within the hypothalamus. In Brain-Endocrine Interaction, Median Eminence: Structure and Function, pp. 306-318. Edited by K. M. Knigge, D. E. Scott, and A. Weindl. Karger: Basel.

BRAWER, J. R. (1972). The fine structure of the ependymal tanycytes at the level of the arcuate nucleus. Journal of Comparative Neurology, 145, 25-42.

BRIGHTMAN, M. W. (1965). The distribution within the brain of ferritin injected into cerebrospinal fluid compartments. I. Ependymal distribution. Journal of Cell Biology, 26, 99-123.

BRIGHTMAN, M. W., and PALAY, S. L. (1963). The fine structure of ependyma in the brain of the rat. Journal of Cell Biology, 19, 415-439.

BRUNI, J. E., MONTEMURRO, D. G., CLATTENBURG, R. E., and SINGH, R. P. (1972). A scanning electron microscopic study of the ependymal surface of the third ventricle of the rabbit, rat, mouse and human brain. Anatomical Record, 174, 407-420.

BRUNI, J. E., MONTEMURRO, D. G., ClAtTENBURG, R. E., and SINGH, R. P. (1973). Scanning electron microscopy of the ependymal surface of the third ventricle after 
silver nitrate test staining. Brain Research, 61, 207-216.

CATHCART, R. S., and WORTHINGTON, W. C. (1964). Currents and clearing action produced in the rat cerebral ventricle by ependymal cilia. Anatomical Record, 148, 269.

CHAMBERLAIN， J. G. (1972). 6Aminonicotinamide (6-AN)-induced abnormalities of the developing ependyma and choroid plexus as seen with the scanning electron microscope. Teratology, 6, 281-286.

ClatTENBURG, R. E., SINGH, R. P., and MONTEMURRO, D. G. (1971).Ultrastructural changes in the preopic nucleus of the rabbit following coitus. Neuroendocrinology, 8, 289-306.

Clattenburg, R. E., SINGH, R. P., and MONTEMURRO, D. G. (1972). Post-coital ultrastructural changes in neurones of the suprachiasmatic nucleus of the rabbit. Zeitschrift fur Zellforschung und Mikroskopische Anatomie, 125, 448-459.

CLEMENTI, F., and MARINI, D. (1972). The surface fine structure of the walls of cerebral ventricles and of choroid plexus in cat. Zeitschrift fur Zellforschung und Mikroskopische Anatomie, 123, 82-95.

COATES, P. W. (1972). Scanning electron microscopic studies of the third ventricle from infant monkey brains disclose supraependymal cells. Journal of Cell Biology, 55, 47a.

COATES, P. W. (1973a). Supraependymal cells and surface specializations on the floor of the monkey third ventricle: Scanning electron microscopic studies. Anatomical Record, 175, 294.

COATES, P.W. (1973b). Supraependymal cells of the monkey third ventricle. American Journal of Anatomy, 136, 533-539.

DALEN, H., SCHLAPFER, W. T., and MAMOON, A. (1971). Cilia on cultured ependymal cells examined by scanning electron microscopy. Experimental Cell Research, 67, 375379

DANIEL, J. L. (1969). Examination of radioactive materials by scanning electron microscopy. In Scanning Electron Microscopy, pp. 295-308. IIT Research Institute: Chicago.

DENCKEN, S. J., and HAGGENDAL, C. J. (1969). Noradrenaline and cerebrospinal fluid. In Zirkumven- trikulare Organe und Liquor, pp. 243-247. Edited by G. Sterba. Fischer: Jena.

DIERICKX, K. (1962). The dendrites of the preoptic neurosecretory nucleus of Rana temporaria and the osmoreceptors. Archives Internationales de Pharmacodynamie et de Therapie, 140, 708-725.

DIRKSEN, E. R., and SATIR, P. (1972). Ciliary activity in the mouse oviduct as studies by transmission and scanning electron microscopy. Tissue and Cell, 4, 389-404.

FLEISCHHAUER, F. (1961). Regional differences in the structure of the ependyma and subependymal layers of the cerebral ventricles of the cat. In Regional Neurochemistry, pp. 279-283. Edited by S. S. Kety, and J. Elkes. Pergamon: New York.

Florey, H. W., POOLE, J. C. F., and MEEK, G. A. (1959). Endothelial cells and 'cement' lines. Journal of Pathology and Bacteriology, 77, 625-636.

FOX, C. A., DE SALVA, S., ZEIT, W., and FISHER, R. (1948). Demonstration of supra-ependymal nerve endings in the third ventricle and synaptic terminals in the cerebral cortex. Anatomical Record, 100, 767.

GARBARSCH, C., and CHRISTENSEN, B. C. (1970). Scanning electron microscopy of aortic endothelial cell boundaries after staining with silver nitrate. Angiologica, 7, 365-373.

GEISSINGER, H. D. (1972). The use of silver nitrate as a stain for scanning electron microscopy of arterial intima and paraffin sections of kidney. Journal of Microscopy, $95,471-481$.

GORDON, J. H., BOLLINGER, J., and REICHLIN, S. (1972). Plasma thyrotropin-releasing hormone after injection into the third ventricle, systemic circulation, median eminence and anterior pituitary. Endocrinology, 91, 696-701.

GOTTLOB, R., and HOFF, H. F. (1968). Histochemical investigations on the nature of large blood vessel endothelial and medial argyrophilic lines and on the mechanism of silver staining. Histochemie, 13, 70-83.

HAGEDOORN, J. (1965). Seasonal changes in the ependyma of the third ventricle of the skunk Mephitis mephitis nigra. Anatomical Record, $151,453-454$.

HELLER, H. (1969). Neurohypophysial hormones in the cerebrospinal fluid.
In Zirkumventrikulare Organe und Liquor, pp. 235-242. Edited by G. Sterba. Fischer: Jena.

HELLER, H., HASAN, S. H., and SAIFI, A. Q. (1968). Antidiuretic activity in the cerebrospinal fluid. Journal of Endocrinology, 41, 273380.

HORSTMANN, E. (1954). Die faserglia des Selachiergehirns. Zeitschrift fur Zellforschung und Mikroskopische Anatomie, 39, 588-617.

ITO, H. (1965). The neurosecretory apparatus in the ventricular wall of the reptilian brain. Journal fur Hirnforschung, 7, 493-498.

KENDALL, J. W., GRIMM, Y., and SHIMSHAK, G. (1969). Relation of cerebrospinal fluid circulation to the ACTH-suppressing effects of corticosteroids in the rat brain. Endocrinology, 85, 200-208.

KLINKERFUSS, G. H. (1964). An electron microscopic study of the ependyma and subependymal glia of the lateral ventricle of the cat. American Journal of Anatomy, 115, 71-100.

KNIGGE, K. M., and SCOTT, D. E. (1970). Structure and function of the median eminence. American Journal of Anatomy, 129, 223-244.

KNIGGE, K. M., and SILVERMAN, A. J. (1972). Transport capacity of the median eminence. In BrainEndocrine Interaction, Median Eminence: Structure and Function, pp. 350-363. Edited by K. M. Knigge, D. E. Scott, and A. Weindl. Karger: Basel.

KNOWLES, F. (1967). Neuronal properties of neurosecretory cells. In Neurosecretion, pp. 8-19. Edited by F. Stutinsky. Springer-Verlag: New York.

KNOWLES, F. (1972). Ependyma of the third ventricle in relation to pituitary function. In Progress in Brain Research, Topics in Neuroendocrinology, pp. 255-270. Edited by J. Ariens Kappers and J. P. Schade. Elsevier: Amsterdam.

KNOWLES, F., and ANAND KUMAR, T. C. (1969). Structural changes, related to reproduction, in the hypothalamus and in the pars tuberalis of the Rhesus monkey. Philisophical Transactions of the Royal Society (B), 256, 357-375.

KOBAYASHI, H. (1972). Median eminence of the hagfish and ependymal absorption in higher vertebrates. In Brain-Endocrine Interaction, Median Eminence: Structure 
and Function, pp. 67-78. Edited by K. M. Knigge, D. E. Scott, and A. Weindl. Karger: Basel.

KOBAYASHI, H., and MATSUI, T. (1969). Fine structure of the median eminence. In frontiers of Neuroendocrinology, pp. 3-46. Edited by W. F. Ganong, and L. Martini. Oxford University Press: New York.

KOBAYASHI, H., MATSUI, T., and ISHII, S. (1970). Functional electron microscopy of the hypothalamic median eminence. International Review of Cytology, 29, 281-381.

KOBAYASHI, H., WADA, M., and UEMURA, H. (1972). Uptake of peroxidase from the third ventricle by ependymal cells of the median eminence. Zeitschrift fur Zellforschung und Mikroskopische Anatomie, 127, 545-551.

KOHNO, K., and USUI, T. (1966). Electron microscopic studies on ependymal cilia and their basal feet on the ventral stalk of the rat subfornical organ. Bulletin of Tokyo Medical and Dental University, 13, 381-405.

KOZLOWSKI, G. P., SCOTT, D. E., and DUDLEY, G. K. (1973). Scanning electron microscopy of the third ventricle of sheep. Zeitschrift fur Zellforschung und Mikroskopische Anatomie, 136, 169-176.

KOZLOWSKI, G. P., SCOTT, D. E., and MURPHY, J. A. (1972). Scanning electron microscopy of the lateral ventricles of sheep. American Journal of Anatomy, 135, 561-566.

LEONHARDT, H. (1966). Uber ependymale tanycyten des III. ventrikels beim kaninchen in elektronenmikroskopischer betrachtung. Zeitschrift fur Zellforschung und Mikroskopische Anatomie, 74, 1-11.

LEONHARDT, H. (1968). Bukettformige strukturen in ependym der regio hypothalamica des III. ventrikels beim kaninchen. Zeitschrift fur Zellforschung und Mikroskopische Anatomie, 88, 297-317.

LEONHARDT, H., and BACKHUSROTH, A. (1969). Synapsenartige kontakte zwischen intraventrikularen axonendigugen und freien oberflachen von ependymzellen des kaninchenhirns. Zeitschrift fur Zellforschung und Mikroskopische Anatomie, 97, 369-376.

LEONHARDT, H., and LINDNER, E. (1967). Marklose nervenfasen im IIl. und IV. ventrikel des kanichen-und katzengehirns. Zeitschrift fur Zell- forschung und Mikroskopische Anatomie, 78, 1-18.

LEONHARDT, $H_{\text {., }}$ and PRIEN, $H$. (1968). Eine weitere art intraventrikularer kolbenformiger axonendigugen aus dem IV. ventrikel des kanichengehirns. Zeitschrift fur Zellforschung und Mikroskopische Anatomie, 92, 394-399.

LÉVÊQUE, T. F. (1972). The medial prechiasmatic area in the rat and $\mathrm{LH}$ secretion. In Brain-Endocrine Interaction, Median Eminence: Structure and Function, pp. 298-305. Edited by K. M. Knigge, D. E. Scott, and A. Weindl. Karger. Basel.

LÉVÊQUE, T. F., and HOFKIN, G. A. (1961). Demonstration of an alcohol-chloroform insoluable periodic acid schiff reactive substance in the hypothalamus of the rat. Zeitschrift fur Zellforschung und Mikroskopische Anatomie, 53, 185-191.

LÉVÊQUE, T. F., and HOFKIN, G. A. (1962). A hypothalamic periventricular PAS substance and neuroendocrine mechanisms. Anatomical Record, 142, 252.

LÉVÊQUE, T. F., STUTINSKY, F., PORTE, A., and STOECKEL, M. E. (1966). Morphologie fine d'une differenciation glandulaire du ressus influndibulaire chez la rat. Zeitschrift fur Zellforschung und Mikroskopische Anatomie, 69, 381-394.

LINFOOT, J. A., GARCIA, J. F., WEI, W., FINK, R., SARIN, R., BORN, J. L., and LAWRENCE, J. H. (1970). Human growth hormone levels in cerebrospinal fluid. Journal of Clinical Endocrinology, 31, 230-232.

LOFGREN, F. (1959). New aspects of the hypothalamic control of the adenohypophysis. Acta Morphologica Neerlando-Scandinavica, 2, 220-229.

LOFGREN, F. (1960). The infundibular recess, a component in the hypothalamo-adenohypophyseal system. Acta Morphologica Neerlando-Scandinavica, 3, 55-78.

LUPPA, H., and FEUSTEL, G. (1971). Location and characterization of hydrolytic enzymes of the IIIrd ventricle lining in the region of the recessus infundibularis of the rat. A study on the function of the ependyma. Brain Research, 29, 253-270.

LURIE, P. O., and WEISS, J. B. (1967). Progresterone in cerebrospinal fluid during human pregnancy. Nature, 215, 1178-1179.

MALINSKY, J. (1968). Fine structure of ependyma in lateral ventricles of human brain. Acta Universitatis Palackianae Olomucensis, 48, 65-72.

MARGOLIS, R. U., and ALTSZUL.AR, $\mathrm{N}$. (1967). Insulin in the cerebrospinal fluid. Nature, 215, 1375-1376.

MATSUI, T., and KOBAYASHI, $H$. (1968). Surface protrusions from the ependymal cells of the median eminence. Archiv für Anatomie, Histologie et Embryologie, 51, 429-436.

MILLHOUSE, O. E. (1971). A golgi study of third ventricle tanycytes in the adult rodent brain. Zeitschrift für Zellforschung und Mikroskopische Anatomie, 121, 1-13.

MILLHOUSE, O. E. (1972). Light and electron microscopic studies of the ventricular wall. Zeitschrift für Zellforschung und Mikroskopische Anatomie, 127, 149-174.

MITRO, A. (1969). Uber ein spezielles ependym im 3. ventrikel der ratte. Experientia, 25, 287.

MOTTA, M., PIVA, F., TIMA, L., ZANISI, M., and MARTINI, L. (1971). Intrahypothalamic localization of the nuclei synthesizing the gonadotropin releasing factors. Journal of Neurovisceral Relations, 10, 32-40.

NANDY, K., and BOURNE, G. H. (1964). Histochemical studies on the ependyma lining the lateral ventricle of the rat with a note on its possible functional significance. Annales d'Histochimie, 9, 305-313.

NOACK, W., DUMITRESCU, L., and SCHWEICHEL, J. U. (1972). Scanning and electron microscopical investigations of the surface structures of the lateral ventricles in the cat. Brain Research, 46, 121-129.

ŌKSC̈HE, A., ZIMMERMANN, P., and OEHMKE, H. J. (1972). Morphometric studies of tubero-eminential systems controlling reproductive functions. In Brain-Endocrine Interaction, Median Eminence: Structure and Function, pp. 142-153. Edited by K. M. Knigge, D. E. Scott, and A. Weindl. Karger: Basel.

ONDO, J. G., ESKAY, R. L., MICAL, R. S., and PORTER, J. C. (1973). Release of LH by LRF injection into the CSF: A transport role for the median eminence. Endocrinology, 93, 231-237.

ONDO, J. G., MICAL, R. S., and PORTER, J. C. (1972). Passage of radioactive substances from CSF to hypophyseal portal blood. Endoçrinology, 91, 1239-1246.

OZTAN, N. (1967). Neurosecretory processes projecting from the preoptic 
nucleus into the third ventricle of Zoarces viviparus (L). Zeitschrift für Zellforschung und Mikroskopische Anatomie, 80, 458-460.

PAVEL, S., and COCULESCU, $M$. (1972). Arginine vasotocin-like activity of cerebrospinal fluid induced by injection of hypertonic saline into the third cerebral ventricle of cats. Endocrinology, 91, 825-827.

PEUTE, J. (1969). Fine structure of the paraventricular organ of Zenopus laevis tadpoles. Zeitschrift für Zellforschung und Mikroskopische Anatomie, 97, 564-575.

PURKINJE, J. E. (1836). Ueber Flimmerbewegungen im gehirn. Muller's Archives für Anatomie und Physiologie, 289.

RINNE, U. K. (1966). Ultrastructure of the median eminence of the rat. Zeitschrift für Zellforschung und Mikroskopische Anatomie, 74, 98-122.

SCHACHENMAYR, W. (1967). Uber die entwicklung von ependym und plexus chorioideus der ratte. Zeitschrift für Zellforschung und Mikroskopische Anatomie, 77, 25-63.

SCHECHTER, J., and WEINER, R. (1972). Ultrastructural changes in the ependymal lining of the media eminence following the intraventricular administration of catecholamine. Anatomical Record, 172, 643-650.

SCHIMRIGK, K. (1966). Uber die wandstruktur der seitenventrikel und des dritten ventrikels beim menschen. Zeitschrift für Zellforschung und Mikroskopische Anatomie, 70, 1-20.

SCHWANITZ, W. (1969). Die topographische venteilung supraependymaler strukturen in den ventrikeln und im zentralkanal des kaninchengehirns. Zeitschrift für Zellforschung und Mikroskopische Anatomie, 100, 536-551.

SCOTT, D. E., DUDLEY, G. K., GIBBS, F. P., and BROWN, G. M. (1972). The mammalian median eminence. In Brain-Endocrine Interaction, Median Eminence: Structure and Function, pp. 35-49. Edited by K. M. Knigge, D. E. Scott, and A. Weindl. Karger: Basel.

SCOTT, D. E., and KNIGGE, K. M. (1970). Ultrastructural changes in the median eminence of the rat following deafferentation of the basal hypothalamus. Zeitschrift für Zellforschung und Mikroskopische Anatomie, 105, 1-32.

SCOTT, D. E., KOZLOWSKI, G. P., and DUDLEY, G. K. (1973). A com- parative ultrastructural analysis of the third cerebral ventricle of the North American mink (Mustela vison). Anatomical Record, 175, 155-168.

SCOTT, D. E., PAULL, W. K., and DUDLEY, G. K. (1972). A comparative scanning electron microscopic analysis of the human cerebral ventricular system. Zeitschrift für Zellforschung und Mikroskopische Anatomie, 132, 203-215.

SHARP, P. J. (1972). Tanycyte and vascular patterns in the basal hypothalamus of Coturnix quail with reference to their possible neuroendocrine significance. Zeitschrift für Zellforschung und Mikroskopische Anatomie, 127, 552-569.

SIERSBAEK-NIELSEN, K., and MOLHOLM HANSEN, J. (1970). Tyrosine and free thyroxine in cerebrospinal fluid in thyroid disease. Acta Endocrinologica, 64, 126-132.

SMOLLER, C. G. (1965). Neurosecretory processes extending into the third ventricle: secretory or sensory? Science, 147, 882.

STUDNICKA, K. F. (1900). Untersuchungen uber der bau des ependyms der nervosen centralorgane. Anatomische Hefte, 15, 303-331.

TENNYSON, V. M., and PAPPAS, G. D. (1962). An electron microscope study of ependymal cells of the foetal, early post-natal, and adult rabbit. Zeitschrift für Zellforschung und Mikroskopische Anatomie, 56, 595618.

TENNYSON, V. M., and PAPPAS, G. D. (1968). Ependyma. In Pathology of the Nervous System, pp. 518-531. Edited by J. Minckler. McGraw Hill: New York.

TIMA, L. (1971). On the site of production of releasing factors. Memoirs of the Society for Endocrinology, 19, 895-901.

TORACK, R. M., and FINKE, E. H. (1971). Evidence for a sequestration of function within the area postrema based on scanning electron microscopy and the penetration of horseradish peroxidase. Zeitschrift für Zellforschung und Mikroskopische Anatomie, 118, 85-96.

USUI, T. (1968). Electron microscopic studies on the ependymal cells of the organon vasculosum laminae terminalis in the adult rat. Bulletin of Tokyo Medical and Dental University, $15,1-18$.

VIGH, B. (1964). Ependymosecretion, secretion Gomori-positive de l'epen- dyme dans l'hypothalamus. Annales d'endocrinologie, 25, 140-141.

VIGH, B., AROS, B., WENGER, T., KORITSANSZKY, S., and CEGLEDI, G. (1963). Ependymosecretion (ependymal neurosecretion). IV. The Gomori-positive secretion of the hypothalamic ependyma of various vertebrates and its relation to the anterior lobe of the pituitary. Acta Biologica Hungarica, 13, 407-419.

VIGH, B., VIGH-TEICHMANN, I., and AROS, B. (1970). Ultrastructure of the CSF contacting neurons of the spinal cord in the newt, Triturus Cristatus. Acta Morphologica Academiae Scientiarum Hungaricae, 18, 369382.

VIGH, B., VIGH-TEICHMANN, I., KORITSANSZKY, S., and AROS, B. (1971). Ultrastructure of the spinal CSF contacting neuronal system in the white leghorn chicken. Acta Morphologica Academiae Scientiarum Hungaricae, 19, 9-24.

VIGH-TEICHMANN, I., VIGH, B., and KORITSANSZKY, S. (1970a). Liquorkontaktneurone im nucleus lateralis tuberis von fischen. Zeitschrift für Zellforschung und Mikroskopische Anatomie, 105, 325-338.

VIGH-TEICHMANN, I., VIGH, B., and KORITSANSZKY, S. (1970b). Liquorkontaktneurone im nucleus paraventricularis. Zeitschrift für Zellforschung und Mikroskopische Anatomie, 103, 483-501.

VIGH-TEICHMANN, I., VIGH, B., KORITSANSZKY, S., and AROS, B. (1970c). Liquorkontaktneurone im nucleus infundibularis. Zeitschrift für Zellforschung und Mikroskopische Anatomie, 108, 17-34.

VORHERR, H., BRADBURY, M. W. B., HOGHOUGHI, M., and KLEEMAN, C. R. (1968). Antidiuretic hormone in cerebrospinal fluid during endogenous and exogenous changes in its blood level. Endocrinology, 83, 246-250.

WEINDL, A., and JOYNT, R. J. (1972a). Ultrastructure of the ventricular walls. Archives of Neurology, 26, 420-427.

WEINDL, A., and JOYNT, R. J. (1972b). The median eminence as a circumventricular organ. In BrainEndocrine Interaction, Median Eminence: Structure and Function, pp. 280-297. Edited by K. M. Knigge, D. E. Scott, and A. Weindl. Karger: Basel.

WEINER, R. I., BLAKE, C. A., and SAWYER, C. H. (1971). Responses 
to intraventricular and intravenous injections of luteinizing hormonereleasing hormone (LH-RH). Proceedings of the 25th International Congress of Physiological Sciences, 9, 600.

WEINER, R. I., TERKEL, J., BLAKE, C. A., SCHALLY, A. V., and SAWYER, C. H. (1972). Changes in serum luteinizing hormone following intraventricular and intravenous injections of luteinizing hormone-releasing hormone in the rat. Neuroendocrinology, 10, 261-272.
WESTERGAARD, E. (1970). The lateral cerebral ventricles and the ventricular walls. Thesis, Andelsbogtrykkeriet i Odense, pp. 1-216.

WESTERGAARD, E. (1972). The fine structure of nerve fibers and endings in the lateral cerebral ventricles of the rat. Journal of Comparative neurology, $144,345-354$.

WISLOCKI, G. B. (1932). The cytology of the cerebrospinal pathway. In Special Cytology, pp. 1485-1521.
Edited by E. V. Cowdry. P. B. Hoeber Inc.: New York.

WITTKOWSKI, W. (1969). Ependymokrinie und rezeptoren in der wand des recessus infundibularis der maus und ihre beziehung zum kleinzelligen hypothalamus. Zeitschrift für Zellforschung und Mikroskopische Anatomie, 93, 530-546.

WORTHINGTON, W. G., and CATHCART, R. S. (1963). Ependymal cilia: distribution and activity in the adult human brain. Science, 139, 221-222. 